DOI 10.37882/2223-2982.2021.07.33

\title{
УЧАСТИЕ КИТАЙСКИХ ЭМИГРАНТОВ В ГРАЖДАНСКОЙ ВОЙНЕ В 1918-1920 ГГ.
}

\section{PARTICIPATION OF CHINESE EMIGRANTS IN THE CIVIL WAR IN 1918-1920}

Xu Hongliang

Summary: The article is devoted to the consideration of the participation of Chinese citizens during the Civil War in Russia. The purpose of the article is to analyze the activities of famous Chinese people who were noted in partisan detachments during the war. The theoretical significance of the study is the possibility of considering the role of the Chinese in lectures and practical classes on «History of the XX century» while studying the topic «Civil war in Russia». The practical significance of the article is the possibility of drawing up portraits of famous Chinese citizens during the war. The scientific novelty of the work is an attempt to generalize scattered materials and archival documents mentioning the actions of Chinese citizens who participated in battles on the side of the Red Army.

Keywords: emigration, Chinese citizens, Civil war in Russia, 1918-1920, Russia, China.

\author{
Сюй Хунлян \\ старший преподаватель, Пекинский педагогический \\ университет; Хэйхэский университет \\ xuhongliang1979@mail.ru
}

Аннотация: Статья посвящена рассмотрению участия китайских граждан в ходе Гражданской войны в России. Целью статьи является анализ деятельности известных китайцев, которые были отмечены в партизанских отрядах в годы войны. Теоретической значимостью исследования является возможность рассмотрения роли китайцев на лекционных и практических занятиях по «Истории XX века» при изучении темы «Гражданская война в России». Практической значимостью статьи является возможность составления портретов знаменитых китайских граждан в годы войны. Научной новизной работы является попытка обобщения разрозненных материалов и архивных документов, упоминающих действия граждан Китая, участвовавших в боях на стороне Красной армии.

Ключевые слова: эмиграция, китайские граждане, Гражданская война в России, 1918-1920 гг., Россия, Китай.
$\mathrm{B}$ начале XX века начинается новый этап китайской эмиграции в России. Безработица, отсутствие финансовых средств и стабильного дохода стали причиной въезда в страну китайских граждан.

Российская Республика нуждалась в трудолюбивых и непритязательных работниках при постройке Транссибирской железной дороги (1891-1916 гг.), а также крепости порт-Владивосток. Как отмечает А.Г. Ларин, заработная плата граждан Китая была значительно ниже, чем денежное вознаграждение российских работников [6, с. 21]. Это объяснялось тем, что китайские работники медленно выполняют необходимые действия. Притеснение китайских граждан, желание защититься от власти капиталистов и помещиков стали причиной активного участия китайцев в Гражданской войне в России.

Участие китайцев в Гражданской войне 1917-1922 года является одной из малоизученных тем российской историографии. Известны работы, посвященные трудовой миграции китайцев во время Гражданской войны следующих исследователей: И. Бабичева [Бабичев, 1959], В. Кима [Ким, 1994], Д. Лаппо [Лаппо, 1959], С.В. Смирнова [Смирнов, 1999], А.Г. Ларина [Ларин, 2003], др. В этих работах освещены некоторые вопросы по истории миграции граждан Китая в Россию, их деятельность на Дальнем Востоке и на Урале. Эти работы носят обобщающий характер, не выделяют отдельных личностей, повлиявших на военные события. В связи с этим, возникает необходимость обобщить и систематизировать деятельность отдельных китайских эмигрантов в России в годы Первой мировой войны. Для решения этой задачи сначала следует обозначить число приехавших из Китая граждан.

Исследователь Пын Мин, проанализировав материалы Российский Республики, указывает, что в Россию до октября 1917 года въехало 200 тыс. китайцев [8, с. 96]. Лю Янчан по данным МИД Китая объясняет, что только в 1907 году во Владивосток прибыло 60-70 тыс. человек [7, с. 13]. А.Г. Ларин, ссылаясь на сведения Китайского посольства, обозначает, что в период с января 1915 по апрель 1917 года в Российскую Республику по железной дороге приехали 159972 китайца [6, с. 67]. Кроме этого, необходимо учитывать деятельность нелегальных эмигрантов, поэтому общая численность может варьироваться от 200 до 250 тыс. человек.

К началу Октябрьской революции китайские трудящиеся проживали на Дальнем Востоке, в Сибири, на Урале, а также в центральных районах Российской Республики. Таким образом, граждане Китая могли принимать участие практически во многих областях страны. По данным Хабаровского крайпартархива, в феврале 1918 года китайские трудящиеся, работавшие в районе Восточного фронта, вступали в красногвардейские отряды, 
в составе которых боролись с белогвардейцами [9].

Летом 1918 года в Петрограде был образован китайский интернациональный отряд. 13 июня 1918 года в Петроградской газете, озаглавленной «Китайские Красные батальоны», указывалось, что численность китайских красноармейцев превышает 1800 человек, но их число постоянно возрастало [2, с. 29].

На Дальнем Востоке массовое вступление китайских трудящихся в борьбу с белогвардейцами впервые было отмечено в марте 1918 года. В начале марта 1918 года китайские рабочие Чепуринского завода и других предприятий города вступило в Красную Гвардию и принимало участие в разгроме контрреволюционного мятежа [10]. На Забайкальском фронте китайцы в интернациональных отрядах боролись против «белогвардейских банд атамана Семенова» [2, с. 31].

Хабаровский совет рабочих и солдатских депутатов организовал интернациональный отряд, значительную часть которого составляли граждане Китая. Отряд участвовал во многих боях на Уссурийском фронте, в частности, он отличился при занятии Каульских высот на р. Уссури 12 августа 1918 года. На Уссурийском фронте сражался отдельный китайский батальон, командиром которого был товарищ Сун Дин-у [2, с. 32].

Одним из руководителей партизанских отрядов был Чин Бао-чуань, который собирал китайских рабочих в свой отряд, рассказывая о революции, о свержении помещиков и капиталистов и прекращении угнетения китайцев. Подразделение Чин Бао-чуяня действовало в составе отряда Иванова вместе с другими отрядами Амурской партизанской армии, которые принимали участие во многих боях с интервентами и белогвардейцами. В качестве примера можно привести бой под Виноградовской заимкой с японо-белогвардейским отрядом, который состоялся 4 февраля 1919 года.

По данным Государственного архива Октябрьской революции и социалистического строительства, китайские рабочие судостроительного завода Лю фу-Чен, Фун За-вя, Чин Дин-шан, Сун Лин-хай, Ши Зя-сян, Фу Зы-чжан, Ван Юн-фу, Ли О-шу, Лю Ю-чен, Ма Ю-дзун, Чжан Жи-шан, Чжан Чао-хо с 1918 года стали бойцами красногвардейских отрядов [3].

Лю Фу-чен стал членом РКП (б) в 1919 году и впоследствии стал организатором коммунистических ячеек китайских бойцов Красной Армии. Рабочий завода «Новый Парвиайнен» Чин Дин-шан и его земляк Сун Лин-хай в начале 1918 года вместе бойцами Красной. Летом 1918 года в составе особого китайского отряда они подавляли мятеж левых эсеров в Петрограде, а также в разгроме белогвардейской армии генерала Н.Н. Юденича на Севе-
ро-Западном фронте [4].

В начале 1918 года в разных районах страны стали формироваться части, состоящие из китайских граждан. Организатором первого китайского батальона в Приднестровье был молодой китайский революционер, коммунист Сан Фу-ян [11, с. 23]. Китайский батальон под командованием Сан Фу-яна входил в состав Тираспольского отряда Красной Армии. В первых же боях в районе Раздельная - Одесса, следуя примеру своих товарищей - русских и украинских рабочих - проявили мужество и упорство.

В 1918 году произошло восстание в полку полковника царской армии Степанова в Нолинске, Уржуме и крупном торговом селе Лебяжье, расположенном на берегу Вятки.

А.Б. Жуйков-Александровский был командиром красногвардейского отряда, в состав которого входило подразделение из 12 китайских добровольцев. Командиром подразделения был Ван Чин-ю, который осуществлял разведку и выяснял информацию о белогвардейцах. В бою, который состоялся под Лебяжьем, особо отличились член партии Щабалин и Ван Чин-ю, который считал себя коммунистом [5, с. 128].

Интерес представляют воспоминания И.Т. Воронцова о партизане Ли Фу. Отряд, в котором участники военных действий совместно вели бои против врагов Советской власти в деревнях Кругликово, Зливке, Саминке, Осиповке, Рогозовке и Дегтяревке [5, с. 114].

Летом 1918 года во Владикавказе находилось около батальона китайских добровольцев, командиром которого был Пау Ти-сан. В дни осады Владикавказа (январьфевраль 1919) самоотверженно сражались с северо-западной стороны китайские добровольцы. В этих боях погибло много китайских товарищей - героев Гражданской войны.

В конце 1919 года Чин Бао-чуянь организовал китайское подразделение при отряде А.Н. Бутрина, который получил название «отряд старика». Осенью 1919 года это подразделение принимало участие в боях под деревней Бесхлебовкой (начало октября), под селом Ерковцы (25 октября) и Тарбагатае (начало ноября).

По линии Амурской железной дороги действовало несколько китайских партизанских отрядов, в том числе отряд Ван Ин-зуна, оперировавший в районе станции Завитой, отряд Ван Вин-Чжана, действовавший около станции Уруша, отряд Тан Юн-сана - у станции Ерофей Павлович, отряд Ку Ма-чена, численностью более 200 человек, действовавший в районе станции Могоши [1]. 
Зимой 1919 года бригадир Чан Си организовал китайских работников и агитировал вступить в отряд красногвардейцев и принимать участие в боях за Советскую власть. Восемь вагонов с китайскими рабочими отправились в Грищино выступать против белогвардейского 13-ого Белоозерского полка. Зимой 1920 года 9-я стрелковая дивизия под руководством Чан Си принимала участие в освобождении Ростова и Северного Кавказа от белогвардейцев.

В 1919-1920 году в Приморье и на Амуре действовало несколько самостоятельных китайских отрядов. Большое количество китайских граждан было в партизанском отряде товарища Ярошенко. Во втором Иманском полку Революционной армии в январе 1920 года сражались две роты китайских партизан.

В 1919-1920 году в Ольгинском уезде действовал китайский отряд численностью 1000 человек под коман- дой революционера Суна, который был участником Китайской революции в 1911 году.

Таким образом, борьба советского народа вместе с передовыми представителями трудящихся Китая против интервентов и белогвардейцев в России была проявлением взаимопомощи и представляла собой фактический союз угнетенных против угнетателей.

Активное участие китайских граждан в ходе Гражданской войны стало причиной улучшения отношения к эмигрантам, завершении притеснений и внешних конфликтов. Использование архивных материалов позволило дать обобщить действия китайских граждан в 19181920 гг. в ходе Гражданской войны. Китайские эмигранты самоотверженно стояли за смену общественного строя, управления страной и возможностью рабочих завода занять передовые места у власти.

1. Амурский облпартархив. Ф. 1. Оп. 1. Д. 253. Л. 61-62.

\section{ЛИТЕРАТУРА}

2. Бабичев И. Участие китайских и корейских трудящихся в Гражданской войне на Дальнем Востоке. Ташкент: Государственное изд-во Узбекской ССР, 1959. $85 \mathrm{c}$.

3. Государственный архив Октябрьской революции и социалистического строительства Ленинградской области. Ф. 4888. Оп. 1. Д. 6228. Л. 2.; Д. 646. Л. 3, 6; Ф. 5302, 0п. 1, Д. 1104, Л. 4.

4. Государственный архив Октябрьской революции и социалистического строительства Ленинградской области. Ф. 4897. 0п. 1. Д. 708. Л. 5; Д. 808. Л. 2.

5. итайские добровольцы в боях за Советскую власть (1918-1922) / Отв. ред. и сост. Лю Юн-ань. М.: Изд-во восточной литературы, 1961. 182 с.

6. Ларин А.Г. Китайские мигранты в России. История и современность. М.: Восточная книга, 2009. 512 с.

7. Ли Юнчан. Китайские рабочие в России и Октябрьская революция. Шицзячжуан, 1986. 234 с.

8. Пын Мин. История советско-китайской дружбы. М.: Соцэкгиз, 1959. 360 с.

9. Хабаровский крайпартархив. Ф. 44. Оп. 1. Д. 281.

10. Центральный государственный архив Красной Армии. Ф. 185. Оп. 9. Д. 50. Л. 484.

11. Якир И.Э. Воспоминания о Гражданской войне. М.: Воениздат, 1957.40 с. 